Jurnal Agro 5(2), 2018

\title{
SELEKSI KACANG TANAH (Arachis hypogaea L.) LOKAL BANGKA TOLERAN CEKAMAN SALINITAS
}

\section{SELECTION OF BANGKA LOCAL GROUNDNUT (Arachis hypogaea L.) TOLERANT TO SALINITY STRESS}

\author{
Gigih Ibnu Prayoga, Eries Dyah Mustikarini, Novin Wandra \\ Program Studi Agroteknologi, Fakultas Pertanian Perikanan dan Biologi, \\ Universitas Bangka Belitung \\ JI. Raya Balunijuk, Kampus Terpadu UBB, Gedung E, Merawang, Bangka, 33172. \\ Korespondensi : gigihibnuprayoga@gmail.com
}

Diterima 04 Oktober 2018/ Disetujui 03 Desember 2018

\begin{abstract}
ABSTRAK
Seleksi cekaman salinitas kacang tanah dilakukan untuk mendapatkan tetua yang toleran terhadap salinitas dan memperbaiki sifat kacang tanah dalam kegiatan pemuliaan tanaman. Informasi genotip unggul kacang tanah toleran terhadap salinitas sangat diperlukan sebagai dasar pemilihan genotip tetua yang adaptif pada lahan salin. Penelitian ini bertujuan untuk memperoleh kacang tanah yang memiliki sifat toleran cekaman salinitas dan menentukan konsentrasi air laut yang dapat ditoleransi oleh tanaman. Penelitian ini dilaksanakan di Kebun Percobaan dan Penelitian, Jurusan Agroteknologi, Fakultas Pertanian Perikanan dan Biologi, Universitas Bangka Belitung, pada bulan Februari-April 2018. Penelitian menggunakan Rancangan Acak Lengkap (RAL) pola split plot dengan 2 ulangan. Petak utama adalah tingkat salinitas yaitu non-salin (kontrol), salinitas rendah, dan salinitas sedang. Anak petak adalah 5 genotip kacang tanah yaitu aksesi lokal (Belimbing dan Arung dalam) dan varietas nasional (Tuban, Kancil, dan Hypoma). Hasil penelitian menunjukkan bahwa varietas Hypoma memiliki karakter jumlah daun dan diameter batang yang paling baik, namun tidak toleran terhadap cekaman salinitas sedang. Aksesi Belimbing merupakan genotip toleran salinitas rendah berdasarkan nilai indeks toleransi cekaman salinitas.
\end{abstract}

Kata kunci: Kacang tanah, genotip, toleransi, salinitas

\begin{abstract}
Selection of groundnut tolerant to salinity stress is carried out to obtain parent genotypes tolerant to salinity and improve the characteristics of groundnut in plant breeding program. The information of superior groundnut genotypes tolerant to salinity is necessary as the basic of genotypes selection adaptive in the saline area. The research aimed to obtain the groundnut tolerant to salinity stress and determine the concentration of seawater that can be tolerated by groundnut. This research was conducted at The Experiment and Research Field, Faculty of Agriculture Fisheries and Biology, University of Bangka Belitung, from February to April 2018
\end{abstract}

Cite this as: Prayoga, G. I. Mustikarini, E. D \& Wandra, N. (2018). Seleksi kacang tanah (Arachis hypogaea L.) lokal Bangka toleran cekaman salinitas. Jurnal Agro, 5(2), 103-113. https://doi.org/10.15575/3366 
The research used Complete Randomized Design (CRD) split plot with two replications. Main plot was concentrations of seawater; non-saline (control), low salinity, and moderate salinity. The subplot was groundnut genotypes of local accessions (Belimbing and Arung Dalam) and national varieties (Tuban, Kancil, and Hypoma). The results of this research indicated that Hypoma has the best result for plant height and diameter of stem, but intolerant to moderate salinity stress. Belimbing was the genotype with low salinity tolerance based on score index of tolerant salinity stress.

Keywords : Groundnut, genotype, tolerant, salinity

\section{PENDAHULUAN}

Kacang tanah (Arachis hypogaea L.) merupakan tanaman polong-polongan atau legum dari famili Papilionaceae. Kacang tanah merupakan komoditas terpenting kedua setelah kedelai yang bernilai ekonomi cukup tinggi karena mengandung 27,9 g protein dan lemak 42,7 g (Departemen Kesehatan, 2015). Menurut Eshun et al. (2013) kacang tanah umumnya memiliki kandungan protein $25-30 \%$, lemak $40-50 \%$, karbohidrat $12 \%$ dan vitamin B1. Marzuki (2007) menyatakan biji kacang tanah banyak digunakan masyarakat sebagai pangan tambahan dalam olahan masakan sehari-hari dan sebagai bahan baku industri seperti keju, minyak dan sabun. Selain itu, kulit kacang tanah dapat dijadikan pakan ternak dan pupuk.

Produksi kacang tanah di Indonesia mengalami penurunan selama dua tahun terakhir. Pada tahun 2015 produksi kacang tanah sebesar 605.449 ribu $\mathrm{t}$ dan pada tahun 2016 produksi menurun menjadi 570.477 ribu t (Badan Pusat Statistik, 2016). Produksi kacang tanah di Kepulauan Bangka Belitung memiliki jumlah produksi yang masih sangat rendah dan mengalami penurunan dari 224 t pada tahun 2014 menjadi $144 \mathrm{t}$ pada tahun 2015 (Badan Pusat Statistik Bangka Belitung, 2016). Kebutuhan kacang tanah nasional masih bergantung dengan negara lain. Hal tersebut dapat dilihat pada tahun 2016 jumlah impor kacang tanah sebanyak $85.557 \mathrm{t}$ dan hanya mengalami penurunan 11,8\% dari tahun 2015 (Badan Pusat Statistik, 2016).

Produksi kacang tanah nasional cenderung menurun setiap tahun hal ini disebabkan penurunan luas area penanaman kacang tanah. Pemanfaatan lahan marginal sangat dibutuhkan untuk meningkatkan produksi kacang tanah seperti lahan pantai (Yuwono, 2009). Bangka Belitung merupakan daerah kepulauan yang memiliki daerah luasan sekitar $81.582 \mathrm{~km}^{2}$, luas daratan 16.281 $\mathrm{km}^{2}$, perairan laut $65.301 \mathrm{~km}^{2}$ dan panjang garis pantai $1.200 \mathrm{~km}^{2}$ (Badan Pusat Statistik Bangka Belitung, 2015). Lahan pantai mempunyai potensi untuk budidaya tanaman karena mempunyai kelebihan yaitu kandungan tanah tidak masam sehingga mengurangi penggunaan kapur, pengolahan lahan lebih mudah dibandingkan dengan tanah Ultisol dan belum tercemar. Namun, kelemahan dari lahan pantai adalah tingkat salinitas yang cukup tinggi. Beberapa lahan pantai di Indonesia diketahui memiliki tingkat salinitas rendah sampai tinggi (Marwanto et al., 2009; Muliawan et al., 2016).

Salah satu upaya pemanfaatan lahan pantai untuk peningkatan produksi kacang tanah adalah menggunakan varietas toleran salinitas. Taufiq et al. (2015) menyatakan 
kacang tanah varietas Domba adalah varietas yang toleran terhadap salinitas dengan pemberian dosis air laut 1,60-1,84 dS $\mathrm{m}^{-1}$ Daya Hamtar Listrik (DHL). Hasil penelitian menunjukan varietas Kelinci mampu bertahan pada cekaman salinitas dengan dosis $7 \mathrm{~g} \mathrm{l}^{-1}$ (Wijayanti et al., 2014). Selain itu, aksesi lokal kacang tanah juga dapat dimanfaatkan untuk budidaya di lahan salin karena sudah beradaptasi dengan lingkungan lokal.

Seleksi aksesi kacang tanah lokal perlu dilakukan untuk mendapatkan genotip kacang tanah yang toleran salinitas untuk kegiatan pemuliaan tanaman dan budidaya tanaman. Aksesi kacang tanah lokal Bangka yang telah didapat dari hasil eksplorasi yaitu 9 aksesi (Kusmiadi et al., 2018). Aksesiaksesi tersebut belum diketahui tingkat toleransinya terhadap salinitas. Oleh karena itu, perlu dilakukan penelitian untuk mengetahui aksesi lokal kacang tanah yang mempunyai kemampuan toleran tinggi terhadap cekaman salinitas.

\section{BAHAN DAN METODE}

Penelitian ini dilaksanakan pada bulan Februari-April 2018 di rumah kaca yang bertempat di Kebun Percobaan dan Penelitian, Jurusan Agroteknologi, Fakultas Pertanian Perikanan dan Biologi, Universitas Bangka Belitung. Bahan yang digunakan yaitu benih kacang tanah, fungisida, pestisida, air laut, tanah topsoil, pupuk (Urea, KCl, SP36) dan kompos.

Penelitian ini menggunakan metode eksperimen. Rancangan yang digunakan adalah Rancangan Acak Lengkap (RAL) pola split plot dengan 2 faktor yaitu tingkat salinitas dan genotip kacang tanah. Pengujian menggunakan RAL karena dilakukan di rumah kaca menggunakan polibag. Petak utama adalah tingkat salinitas yaitu $\mathrm{SO}=$ kontrol, $0 \mathrm{dS} \mathrm{m}^{-1}$ (Non salin), $\mathrm{S} 1=1,16 \mathrm{dS} \mathrm{m}^{-1}$ (Salinitas rendah) dan $\mathrm{S} 2=2,32 \mathrm{dS} \mathrm{m}^{-1}$ (Salinitas sedang). Anak petak adalah 5 genotip kacang tanah yaitu aksesi lokal (G1= Belimbing dan G2= Arung dalam) dan varietas nasional ( $G 3=$ Tuban, G4= Kancil, G5= Hypoma).

\section{Metode skrining cekaman salinitas}

Benih ditanam pada polibag yang telah disediakan lubang tanam sedalam $2-3 \mathrm{~cm}$ sebanyak 2 benih per polibag. Benih yang telah hidup selama 7 hari akan dilakukan penjarangan untuk mengambil bibit yang baik.

Tanaman dipelihara dengan kadar salinitas sampai batas ketahanan kacang tanah yaitu 70 HST (Taufiq et al., 2015). Pemberian perlakuan sesuai dosis yang telah ditentukan yaitu 0\%, 25\% dan 50\% air laut. Air laut diambil dari pantai Air Anyir di kabupaten Bangka. Air laut kemudian diencerkan dengan menambahkan air tawar hingga mencapai konsentrasi perlakuan yang ditentukan dengan volume total 500 $\mathrm{ml}$. Penyiraman dengan air laut dilakukan sekali sehari sesuai dengan perlakuan.

Penentuan tingkat salinitas berdasarkan perhitungan $\mathrm{DHL}$ air laut dengan menggunakan alat TDS, satuan yang digunakan yaitu ppm dikonversikan menjadi dS $\mathrm{m}^{-1}$. Perhitungan konsentrasi salinitas sebagai berikut :

SO (non salin) $=0 \mathrm{dS} \mathrm{m}^{-1}$

$\mathrm{S} 1$ (salinitas rendah) $=1,16 \mathrm{dS} \mathrm{m}^{-1}$

S2 (salinitas sedang) $=2,32 \mathrm{dS} \mathrm{m}^{-1}$

Kriteria salinitas berdasarkan Pusat Penelitian dan Pengembangan Tanaman Pangan (2017), jika konsentrasi kandungan garam $<1 \mathrm{dS}^{-1}$ (tidak salin), 1-2 dS $\mathrm{m}^{-1}$ (salinitas rendah), 2-4 dS $\mathrm{m}^{-1}$ (salinitas 
sedang), 4.0-8,0 $\mathrm{dS} \mathrm{m}^{-1}$ (salinitas agak tinggi) dan 8,8-16,0 dS $\mathrm{m}^{-1}$ (salinitas tinggi).

Total terdapat 18 kombinasi perlakuan yang terdiri dari 2 ulangan sehingga terdapat 36 unit percobaan. Tanaman yang digunakan sebanyak 5 tanaman sehingga jumlah populasi tanaman adalah 180 dan sampel yang diamati adalah 3 tanaman.

\section{Parameter Pengamatan}

Karakter tanaman yang diamati yaitu kandungan klorofil, volume akar, berat kering akar, berat kering tanaman, tinggi tanaman, jumlah daun, diameter batang, panjang akar, jumlah polong, dan bobot 100 biji.

Data hasil pengamatan dianalisis menggunakan analisis varian (uji F) dengan taraf $5 \%$ dan $1 \%$. Apabila terdapat taraf perlakuan yang berpengaruh nyata, maka akan dilanjutkan dengan uji lanjut Duncan's Multiple Range Test (DMRT) dengan taraf $5 \%$ menggunakan program aplikasi DSAASTAT. Jika tidak terjadi interaksi antara cekaman dengan genotip, maka karakter yang tidak berinteraksi akan dianalisis terpisah untuk mengetahui pengaruh mandiri dari setiap taraf masing-masing perlakuan.

Tingkat toleransi kacang tanah terhadap cekaman salinitas dinilai dengan indeks toleransi terhadap cekaman (Fischer \& Maurer, 1978) dengan rumus:

$$
\mathrm{S}=(1-\mathrm{Y} / \mathrm{Yp}) /(1-\mathrm{X} / \mathrm{Xp})
$$

\section{dimana :}

$\mathrm{S}=$ Indeks toleransi cekaman

$Y p=$ Rata-rata suatu genotipe yang mendapatkan cekaman

$Y=$ Rata-rata suatu genotipe yang tidak mendapat cekaman

$\mathrm{Xp}=$ Rata-rata dari seluruh genotipe yang mendapatkan cekaman

$\mathrm{X}=$ Rata-rata dari seluruh genotipe yang tidak mendapatkan cekaman
Nilai S dihitung berdasarkan semua karakter yang diamati. Kriteria untuk menentukan tingkat toleransi terhadap cekaman dikelompokkan menjadi toleran jika nilai $\mathrm{S}<0,5$, medium jika nilai $0,5<\mathrm{S}<$ 1 , dan peka terhadap cekaman jika nilai $S>$ 1.

\section{HASIL DAN PEMBAHASAN}

Hasil analisis varian pada karakter tanaman kacang tanah (Tabel 1) menunjukkan bahwa perlakuan cekaman salinitas berpengaruh tidak nyata terhadap kandungan klorofil, namun berpengaruh nyata pada karakter volume akar, berat kering akar dan berat kering tajuk. Pengaruh sangat nyata cekaman ditunjukkan pada karakter tinggi tanaman, jumlah daun, diameter batang, panjang akar, jumlah polong dan bobot 100 biji berpengaruh sangat nyata.

Interaksi cekaman salinitas dengan genotip ditunjukkan pada karakter bobot 100 biji, berat kering akar dan berat kering tajuk (Tabel 1). Karakter-karakter ini selanjutnya dianalisis sesuai taraf perlakuan dengan uji DMRT untuk melihat pengaruh dari masing-masing perlakuan.

Hasil analisis interaksi menujukkan varietas Hypoma memiliki hasil terbaik pada karakter berat kering akar dan berat kering tajuk pada perlakuan non salin dan saliniatas rendah (Tabel 2 dan 3). Hal ini diduga karena jumlah daun varietas Hypoma yang banyak sehingga fotosintesis tetap berjalan baik. Fotosintesis meningkat mengakibatkan berat kering tanaman semakin berat karena pengambilan $\mathrm{CO}_{2}$ yang tinggi (Evita, 2012).

Perlakuan cekaman salinitas sedang mempengaruhi pertumbuhan tanaman yang ditandai oleh menurunnya berat 
kering akar dan berat kering tajuk, bahkan mengalami kematian pada saat memasuki fase generatif. Penurunan bobot kering tajuk dan akar merupakan indikasi bahwa nilai kritis terhadap cekaman salinitas (Taufiq et al., 2015). Perlakuan cekaman salinitas sedang mengakibatkan tanaman menunjukkan gejala cekaman salinitas yaitu daun yang mulai menguning. Fase kritis cekaman salinitas ditandai dengan daun mulai mengalami kerusakan karena toksisitas akibat akumulasi $\mathrm{Na}^{+}$dalam daun (Yunita et al., 2018). Ma'ruf (2016) menjelaskan bahwa cekaman salinitas menyebabkan tanaman mengalami toksisitas garam sehingga tanaman menjadi kekurangan air.

Tabel 1. Analisis Varian Pengaruh Cekaman Salinitas Terhadap Pertumbuhan Genotip Kacang Tanah.

\begin{tabular}{lcccccc}
\hline \multirow{2}{*}{ Karakter } & \multicolumn{2}{c}{ Salinitas } & \multicolumn{2}{c}{ Genotip } & \multicolumn{2}{c}{ Interaksi } \\
\cline { 2 - 7 } & F.Hit & Pr>F & F.Hit & Pr>F & F.Hit & Pr>F \\
\hline Tinggi Tanaman & 211,62 & $0,0005^{* *}$ & 17,68 & $5,7091^{\text {tn }}$ & 1,63 & $0,2123^{\text {tn }}$ \\
Jumlah Daun & 40,48 & $0,0067^{* *}$ & 26,92 & $<0,001^{* *}$ & 2,39 & $0,8375^{\text {tn }}$ \\
Diameter batang & 31,73 & $0,0095^{* *}$ & 8,37 & $0,0018^{* *}$ & 0,89 & $0,5512^{\text {tn }}$ \\
Kandungan klorofil & 9,06 & $0,0535^{\text {tn }}$ & 0,69 & $0,6106^{\text {tn }}$ & 0,91 & $0,5367^{\text {tn }}$ \\
Volume Akar & 27,97 & $0,0114^{*}$ & 2,79 & $0,0746^{\text {tn }}$ & 1,19 & $0,3748^{\text {tn }}$ \\
Panjang akar & 333,87 & $0,0002^{* *}$ & 1,07 & $0,4106^{\text {tn }}$ & 1,11 & $0,4157^{\text {tn }}$ \\
Berat kering akar & 27,36 & $0,0118^{*}$ & 7,27 & $0,0032^{* *}$ & 3,97 & $0,0160^{*}$ \\
Berat kering tajuk & 25,41 & $0,0131^{*}$ & 3,27 & $0,0491^{*}$ & 3,32 & $0,0330^{*}$ \\
Jumlah Polong & 277,31 & $0,0003^{* *}$ & 2,54 & $0,0938^{\text {tn }}$ & 0,88 & $0,5588^{\text {tn }}$ \\
Bobot 100 biji & 1664,19 & $<0,001^{* *}$ & 8,18 & $0,0020^{* *}$ & 8,18 & $0,0007^{* *}$ \\
\hline
\end{tabular}

Keterangan :

KK : Koefisien Keragaman

** : : Berpengaruh Sangat Nyata (1\%)

tn : tidak berpengaruh nyata

* : Berpengaruh Nyata (5\%)

Aksesi Belimbing dan varietas Tuban memiliki karakter berat kering akar dan tajuk yang rendah pada perlakuan non-salin dan salinitas sedang. Akan tetapi pada perlakuan cekaman salinitas sedang, aksesi Belimbing dan varietas Tuban tetap hidup sedangkan genotip lainnya mengalami kematian (Tabel 2 dan 3). Pertumbuhan akar dan tajuk dipengaruhi oleh ketersediaan air dan unsur hara tanaman. Kondisi tercekam menyebabkan pasokan air dan unsur hara tidak tersedia karena akumulasi garam yang berlebihan. Salinitas menghambat penyerapan air oleh akar karena potensial osmotik larutan meningkat akibatnya pergerakan air dari tanah ke akar terhambat (Daeli et al., 2013). Aini et al., (2014) menyatakan penurunan bobot kering tajuk dan akar genotip kedelai pada kondisi salinitas disebabkan oleh potensial tanah, meningkatnya serapan $\mathrm{Na}$ dan $\mathrm{Cl}$ sehingga terjadi kekeringan fisiologis. Salinitas menyebabkan kekurangan air tanaman karena besarnya potensial osmotik pada akar (Taufiq \& Purwaningrahayu, 2013), dan terjadi penurunan volume akar sebagai respon terhadap kekurangan air (Torey et al., 2013). Respon tanaman terhadap penggunaan air menunjukkan semakin baik pertumbuhan tanaman, maka semakin banyak penggunaan air oleh tanaman. 
Tabel 2. Interaksi Genotip Kacang Tanah dengan Cekaman Salinitas pada Karakter Berat Kering Akar.

\begin{tabular}{|c|c|c|c|}
\hline \multirow{2}{*}{ Genotip } & \multicolumn{3}{|c|}{ Salinitas } \\
\hline & non-salin & rendah & sedang \\
\hline & & --- g----- & \\
\hline \multirow{2}{*}{ Belimbing } & $2,34 \mathrm{C}$ & $2,50 \mathrm{~B}$ & $0,45 \mathrm{~A}$ \\
\hline & a & $a$ & $\mathrm{~b}$ \\
\hline Arung & $3,30 \mathrm{C}$ & $3,17 \mathrm{~B}$ & $0,00 \mathrm{~A}$ \\
\hline Dalam & a & $a$ & b \\
\hline \multirow{2}{*}{ Tuban } & $4,79 \mathrm{BC}$ & $3,30 \mathrm{~B}$ & $0,81 \mathrm{~A}$ \\
\hline & $\mathrm{a}$ & b & c \\
\hline \multirow{2}{*}{ Kancil } & $5,83 \quad$ B & $3,78 \mathrm{~B}$ & $0,00 \mathrm{~A}$ \\
\hline & $\mathrm{a}$ & b & c \\
\hline \multirow{2}{*}{ Hypoma } & $9,55 \mathrm{~A}$ & $4,89 \mathrm{~A}$ & $0,00 \mathrm{~A}$ \\
\hline & $\mathrm{a}$ & b & C \\
\hline
\end{tabular}

Keterangan: Angka yang diikuti huruf kapital yang sama pada kolom yang sama menunjukkan tidak beda nyata, angka yang diikuti huruf kecil yang sama pada baris yang sama menunjukkan tidak beda nyata pada uji DMRT taraf $5 \%$.

Aksesi Arung Dalam memiliki rata-rata berat kering akar dan berat kering tajuk lebih baik dibandingkan dengan aksesi Belimbing pada perlakuan non salin dan salinitas rendah (Tabel 2 dan 3). Perbedaan karakter kedua aksesi ini disebabkan oleh kemampuan genetik tanaman dalam menggendalikan lingkungan tercekam. Respon tanaman pada cekaman salinitas berbeda pada spesies atau genotipe yang berbeda (Aini et al., 2012). Aksesi kacang tanah lokal mempunyai pertumbuhan yang berbeda kemungkinan disebabkan oleh kekerabatan yang jauh antar keduanya sehingga pertumbuhan pada masing-masing aksesi berbeda. Menurut Kusmiadi et al. (2018) aksesi Arung dalam dan aksesi Belimbing mempunyai kekerabatan pada kelompok yang berbeda. Hal ini menunjukkan bahwa respon pertumbuhan kedua aksesi ini dipengaruhi oleh genetik yang berbeda-beda. Kedua aksesi ini diduga memiliki sifat genetik yang sudah menyesuaikan dengan kondisi tanah Bangka yang termasuk sub-optimal atau cekaman.

Tabel 3. Interaksi Genotip Kacang Tanah dengan Cekaman Salinitas pada Karakter Berat Kering Tajuk.

\begin{tabular}{lccc}
\hline \multirow{2}{*}{ Genotip } & \multicolumn{3}{c}{ Salinitas } \\
\cline { 2 - 4 } & non salin & rendah & sedang \\
\hline \multirow{4}{*}{ Belimbing } & $13,69 \mathrm{C}$ & $----\mathrm{g}----$ \\
Arung & $\mathrm{a}$ & $\mathrm{a}, 85 \mathrm{~B}$ & $13,12 \mathrm{~A}$ \\
dalam & $18,4 \mathrm{BC}$ & $21,71 \mathrm{AB}$ & $0,00 \mathrm{~A}$ \\
Tuban & $\mathrm{a}$ & $\mathrm{a}$ & $\mathrm{b}$ \\
& $20,13 \mathrm{BC}$ & $24 \mathrm{AB}$ & $3,12 \mathrm{~A}$ \\
Kancil & $\mathrm{a}$ & $\mathrm{a}$ & $\mathrm{b}$ \\
& $29,17 \mathrm{AB}$ & $22,15 \mathrm{AB}$ & $0,00 \mathrm{~A}$ \\
Hypoma & a & $\mathrm{b}$ & $\mathrm{C}$ \\
& $40,56 \mathrm{~A}$ & $34,37 \mathrm{~A}$ & $0,00 \mathrm{~A}$ \\
& \multicolumn{4}{c}{$\mathrm{a}$} & $\mathrm{b}$ & $\mathrm{C}$ \\
\hline Keterangan: & Angka yang & diikuti huruf & kapital \\
& yang sama pada kolom yang sama \\
& menunjukkan tidak beda nyata, \\
& angka yang diikuti huruf kecil yang \\
& sama pada baris yang & sama \\
& menunjukkan tidak beda nyata \\
& pada uji DMRT taraf $5 \%$
\end{tabular}

Hasil uji dwi arah pada karakter bobot 100 biji menunjukkan bahwa interaksi antara varietas Hypoma dengan perlakuan non-salin memiliki bobot 100 biji yang tinggi namun tidak berbeda nyata dengan aksesi Belimbing. Perlakuan cekaman salinitas rendah dan sedang tidak bisa dilakukan perhitungan bobot 100 biji karena polong pada tanaman tidak membentuk biji (Tabel 4).

Hal ini diduga dipengaruhi oleh kandungan garam yang tinggi pada tanaman sehingga menyebabkan tanaman keracunan dan mengalami kekeringan fisiologis. Hal ini mengakibatkan energi yang diperlukan untuk pembentukan biji yang optimal menjadi tidak tersedia sehingga polong menjadi hampa. Pada kondisi salin, energi 
(ATP) yang diperlukan untuk pembentukan asimilat digunakan sebagai pertahanan terhadap cekaman (Wijayanti et al., 2014).

Tabel 4. Interaksi Genotip Kacang Tanah dengan Cekaman Salinitas pada Karakter Bobot 100 Biji.

\begin{tabular}{lccc}
\hline & \multicolumn{3}{c}{ Salinitas } \\
\cline { 2 - 4 } Genotip & non salin & rendah & Sedang \\
\hline \multirow{4}{*}{ Belimbing } & $72,88 \mathrm{~A}$ & $0,00 \mathrm{~A}$ & $0,00 \mathrm{~A}$ \\
& $\mathrm{a}$ & $\mathrm{b}$ & $\mathrm{B}$ \\
Arung & $40,36 \mathrm{C}$ & $0,00 \mathrm{~A}$ & $0,00 \mathrm{~A}$ \\
Dalam & $\mathrm{a}$ & $\mathrm{b}$ & $\mathrm{B}$ \\
Tuban & $55,98 \mathrm{~B}$ & $0,00 \mathrm{~A}$ & $0,00 \mathrm{~A}$ \\
& $\mathrm{a}$ & $\mathrm{b}$ & $\mathrm{B}$ \\
Kancil & $55,05 \mathrm{~B}$ & $0,00 \mathrm{~A}$ & $0,00 \mathrm{~A}$ \\
& $\mathrm{a}$ & $\mathrm{b}$ & $\mathrm{B}$ \\
Hypoma & $75,56 \mathrm{~A}$ & $0,00 \mathrm{~A}$ & $0,00 \mathrm{~A}$ \\
& a & $\mathrm{b}$ & $\mathrm{B}$ \\
\hline Keterangan: & Angka yang & diikuti huruf kapital \\
& yang sama pada kolom yang sama \\
& menunjukkan tidak beda nyata, \\
& angka yang diikuti huruf kecil yang \\
& sama pada baris yang sama \\
& menunjukkan tidak beda nyata \\
& pada uji DMRT taraf 5\%.
\end{tabular}

Hal ini menyebabkan penurunan fotosintat yang menghambat proses translokasi hara ke daun sehingga daun menguning dan kemampuan pembentukan biji pada polong menurun (Muharam, 2017). Cabot et al. (2014) menyatakan cekaman salinitas menyebabkan terjadinya penuaan daun yang lebih cepat sehingga menurunkan hasil biji.

Salinitas mempengaruhi pertumbuhan tanaman melalui penghambatan proses metabolisme tanaman seperti penurunan tekanan osmotik, pembentukan protein, laju fotosintesis, aktivitas enzim dan keseimbangan hormon (Kasno \& Harnowo, 2009). Akumulasi $\mathrm{Na}$ dan $\mathrm{Cl}$ yang berlebihan dalam sitoplasma menyebabkan penurunan pertumbuhan dan perkembangan tanaman (Yuniati, 2004).

Penyerapan $\mathrm{Na}$ dan $\mathrm{Cl}$ dalam jumlah yang berlebih akan menyebabkan keracunan bagi tanaman (Nasyirah et al., 2015), menurunkan indeks kandungan klorofil dan berat biji (Taufiq \& Purwaningrahayu, 2013), dan mempengaruhi jumlah daun, luas daun dan berat kering tajuk (Hetharie, 2008). Menurut Taufiq et al. (2015), peningkatan salinitas juga berpengaruh nyata terhadap tinggi tanaman pada saat berumur 25 HST hingga 85 HST (Tabel 5).

Perbedaan penampilan antar genotip kacang tanah terlihat pada karakter jumlah daun, diameter batang, berat kering akar, bobot 100 biji, berat kering tajuk, dan tinggi tanaman. Tidak terdapat perbedaan penampilan antar genotip pada karakter kandungan klorofil, volume akar, panjang akar dan jumlah polong (Tabel 1).

Tabel 5. Rerata Fenotipe Tanaman Kacang Tanah pada Perlakuan Cekaman Salinitas

\begin{tabular}{ccccccc}
\hline \multirow{2}{*}{ Salinitas } & \multicolumn{6}{c}{ Karakter } \\
\cline { 2 - 7 } & $\begin{array}{c}\text { Tinggi } \\
\text { tanaman }\end{array}$ & $\begin{array}{c}\text { Jumlah } \\
\text { Daun }\end{array}$ & $\begin{array}{c}\text { Diameter } \\
\text { batang }\end{array}$ & $\begin{array}{c}\text { Volume } \\
\text { Akar }\end{array}$ & Panjang akar & $\begin{array}{c}\text { Jumlah } \\
\text { Polong }\end{array}$ \\
\hline non salin & $\mathbf{2 4 , 7 3 a}$ & $\mathbf{4 8 , 7 4 a}$ & $\mathbf{5 , 1 3 a}$ & $\mathbf{3 4 , 4 5 a}$ & $\mathbf{5 0 , 7 2 a}$ & $\mathbf{3 1 , 6 3 a}$ \\
rendah & $15,90 \mathrm{~b}$ & $34,68 \mathrm{~b}$ & $\mathbf{4}, 47 \mathrm{~b}$ & $\mathbf{2 9 , 7 6 a}$ & $46,41 \mathrm{~b}$ & $\mathbf{2 0 , 1 2 \mathrm { b }}$ \\
sedang & $11,89 \mathrm{c}$ & $18,52 \mathrm{c}$ & $\mathbf{3 , 9 6 c}$ & $6,43 \mathrm{~b}$ & $18,05 \mathrm{c}$ & $1,02 \mathrm{c}$ \\
\hline
\end{tabular}

Keterangan: Angka yang diikuti oleh huruf yang sama pada kolom yang sama menunjukkan tidak berbeda nyata pada uji DMRT pada taraf $5 \%$ 
Hasil analisis DMRT memperlihatkan bahwa varietas Hypoma merupakan genotip yang paling baik pertumbuhannya dibandingkan dengan varietas Tuban, varietas Kancil, aksesi Arung Dalam dan aksesi Belimbing. Varietas Hypoma memberikan karakter terbaik pada karakter jumlah daun dan diameter batang (Tabel 6). Hal ini diduga karena kemampuan adaptasinya yang membantu dalam proses pertumbuhan. Adaptasi tanaman terhadap lingkungan merupakan bentuk interaksi antara genetik dengan lingkungan. Hetharie (2008) menyatakan bahwa peranan dari banyak gen menjadi penentu toleransi tanaman terhadap cekaman lingkungan sehingga diduga bahwa pertumbuhan yang lebih baik pada varietas Hypoma dipengaruhi oleh faktor genetik dari banyak gen (poligenik).

Varietas Tuban memiliki karakter jumlah daun paling rendah namun tidak berbeda nyata dengan aksesi Arung Dalam dan Kancil (Tabel 6). Hal ini diduga sebagai respon tanaman terhadap cekaman salinitas sehingga setiap genotip memiliki karakter yang berbeda. Kondisi tercekam akan memacu tumbuhan untuk beradaptasi demi meningkatkan ketahanannya (Djukri, 2009). Adaptasi itu dapat ditunjukkan dengan terbentuknya molekul-molekul tertentu di dalam sel, seperti prolin dan berbagai asam amino bebas lainnya, yang berperan dalam peningkatan ketahanan terhadap cekaman salin. Kristiono et al., (2013) menyatakan respon ketahanan garam pada tanaman sebagai mekanisme toleransi dan penghindaran yang efektif pada tingkat salinitas sedang dan rendah. Penghindaran garam pada tanaman melibatkan adaptasi fisiologi untuk meminimalkan konsentrasi garam didalam sel atau eksklusi fisiologis oleh membran akar (Koyro et al., 2011). Peningkatan konsentrasi salinitas menimbulkan keracunan garam pada tanaman kacang tanah yang menyebabkan tanaman kerdil dan daun menguning akibat dari kandungan $\mathrm{Na}$ dan $\mathrm{Cl}$ yang menganggu proses fotosintesis. Penghambatan proses metabolisme ini menyebabkan tanaman memiliki berat kering yang rendah seperti pada aksesi Belimbing.

Tanaman yang tumbuh di tanah salin akan mengakumulasi banyak ion $\mathrm{Na}$ dan $\mathrm{Cl}$ yang akan mengganggu penyerapan hara lain seperti ion $\mathrm{Ca}, \mathrm{K}, \mathrm{N}$ dan $\mathrm{P}$ (Purwaningrahayu \& Taufiq, 2017). Ion $\mathrm{Na}$ dan $\mathrm{Cl}$ dapat berperan sebagai racun yang dapat merusak DNA dan protein (Muharam, 2017). Tanah salin diidentifikasi oleh aktifitas ion $\mathrm{Na}, \mathrm{Mg}$ dan $\mathrm{Cl}$ ekstrim yang menyebabkan ketidakseimbangan unsur hara serta menurunkan pertumbuhan dan kualitas tanaman.

Tabel 6. Rerata Pertumbuhan Tanaman Beberapa Genotip Kacang Tanah

\begin{tabular}{lccccc}
\hline & \multicolumn{5}{c}{ Genotip } \\
\cline { 2 - 6 } \multicolumn{1}{c}{ Karakter } & Belimbing & Arung Dalam & Tuban & Kancil & Hypoma \\
\hline Jumlah Daun & $35,65 \mathrm{~b}$ & $26,70 \mathrm{c}$ & $25,81 \mathrm{c}$ & $26,31 \mathrm{c}$ & $\mathbf{5 5 , 4 3 a}$ \\
Diameter Batang & $4,31 \mathrm{~b}$ & $4,12 \mathrm{~b}$ & $4,35 \mathrm{~b}$ & $4,33 \mathrm{~b}$ & $\mathbf{5 , 5 0 a}$ \\
\hline
\end{tabular}

Keterangan: Angka yang diikuti oleh huruf yang sama pada baris yang tidak berbeda nyata pada uji DMRT pada taraf $5 \%$

Penentuan tingkat toleransi tanaman juga dilakukan menggunakan indeks toleransi cekaman. Berdasarkan nilai yang diperoleh tanaman dapat digolongkan dalam kriteria toleran, medium, dan peka terhadap cekaman (Tabel 7 dan 8). Hasil 
indeks toleransi pada cekaman salinitas rendah, aksesi Belimbing tergolong toleran untuk volume akar, berat kering akar dan berat kering tajuk. Aksesi Arung dalam tergolong toleran pada karakter berat kering akar dan berat kering tajuk. Varietas Tuban toleran untuk karakter berat kering tajuk. Varietas Kancil toleran pada kandungan klorofil dan varietas Hypoma toleran untuk karakter jumlah polong (Tabel 7).

Hasil analisis indeks toleransi cekaman salinitas sedang pada tanaman kacang tanah menunjukkan bahwa aksesi Belimbing toleran untuk berat kering tajuk, varietas Tuban toleran pada karakter panjang akar, dan varietas Hypoma tergolong toleran toleran pada karakter kandungan klorofil (Tabel 8).

Varietas Hypoma meskipun memiliki pertumbuhan yang lebih baik di kondisi tercekam, namun memiliki tingkat sensitivitas yang tinggi terhadap cekaman salinitas. Hal ini berarti karakter-karakter pada varietas Hypoma mengalami penurunan jika dibandingkan dengan kondisi normal. Namun, pertumbuhan varietas Hypoma pada salinitas rendah masih lebih baik dari genotip lainnya karena memang lebih unggul pada kondisi normal.

Aksesi Belimbing memiliki beberapa karakter yang menunjukan toleran cekaman salinitas rendah dibandingkan genotip lainnya. Hal ini menunjukkan bahwa aksesi Belimbing memiliki tingkat sensitivitas cekaman yang rendah sehingga mampu mempertahankan pertumbuhannya seperti pada kondisi lingkungan normal. Mekanisme toleransi tanaman terhadap pengaruh salinitas mencakup perubahan morfologi, fisiologi maupun proses biokimia. Tanaman kacang tanah meningkatkan pertumbuhan akar dan menurunkan pertumbuhan daun merupakan respon ketahanan dari tanaman terhadap cekaman salinitas. Menurut Kristiono et al., (2013), lignifikasi akar diperlukan tanaman untuk penyesuaian osmotik untuk memelihara turgor yang diperlukan dalam pertumbuhan tanaman dan aktivitas normal.

Berdasarkan hasil penelitian, varietas Hypoma merupakan varietas paling adaptif untuk dibudidayakan pada lahan salin dibandingkan dengan varietas dan aksesi kacang tanah lainnya. Hal ini karena varietas Hypoma memiliki karakter pertumbuhan yang paling baik pada perlakuan cekaman salinitas rendah pada karakter berat kering tajuk, berat kering akar, jumlah daun dan diameter batang. Aksesi Belimbing merupakan aksesi lokal yang dapat dijadikan sebagai sumber gen toleran cekaman salinitas rendah, terutama pada karakter volume akar, berat kering akar, dan berat kering tajuk. Selain itu, aksesi Belimbing juga mampu bertahan hidup pada perlakuan cekaman salinitas sedang.

\section{SIMPULAN}

1. Genotip kacang tanah yang memiliki karakter pertumbuhan paling baik pada lingkungan cekaman salinitas rendah adalah varietas Hypoma.

2. Genotip kacang tanah yang menunjukkan lebih banyak karakter toleran pada cekaman salinitas rendah adalah aksesi lokal Belimbing.

\section{Ucapan Terimakasih}

Terimakasih disampaikan kepada Universitas Bangka Belitung yang telah mendanai penelitian ini melalui skema Penelitian Dosen Tingkat Universitas tahun 2018 dengan nomor SK 884/UN50/PM/2018. 


\section{DAFTAR PUSTAKA}

Aini, N., Mapfumo, E., Rengel, Z., \& Tang, C. (2012). Ecophysiological responses of Melaleuca species to dual stresses of water logging and salinity. Journal of Plant Physiology and Biochemistry, 4(4),52-58. http://doi.org/10.5897/IJPPB11.032

Aini, N., Sumiya, W. D. Y., Syekhfani, Dyah, R. P., \& Setiawan, A. (2014). Kajian pertumbuhan, kandungan klorofil dan hasil beberapa genotip tanaman kedelai (Glycine max L .) Pada kondisi salinitas. In Prosiding Seminar Nasional Lahan Suboptimal (pp. 319-325).

Badan Pusat Statistik (2015). Investasi di provinsi kepulauan Bangka Belitung tahun 2015. Retrieved September 18, 2017,from http://dkp.babelprov.go.id/content/p otensi-investasi-di-provinsi-kepulauanbangka-belitung-tahun-2015

Badan Pusat Statistik. (2016). Produksi kebutuhan pangan Indonesia. Retrieved from

http://babel.bps.go.id/linkTableDinam is/view/id/385

Badan Pusat Statistik Bangka Belitung. (2016). BPS Provinsi Kepulauan Bangka Belitung No. 46/07/19/TH.XIV. Berita Resmi Statistik.

Cabot, C., Sibole, J., Barceló, J., \& Poschenrieder, C. (2014). Lessons from crop plants struggling with salinity. Plant Science (Vol. 226). http://doi.org/10.1016/j.plantsci.2014 .04 .013

Daeli, N. D. S., Putri, L. A. P., \& Nuriadi, I. (2013). Pengaruh radiasi gamma terhadap tanaman kacang hijau (Vigna radiata L.) pada Kondisi Salin. Agroekoteknologi, 1(2), 227-237.
Djukri. (2009). Cekaman salinitas terhadap pertumbuahn tanaman. In Prosiding Seminar Nasional Penelitian, Pendidikan, dan Penerapan MIPA (pp. 49-55).

Eshun, G., Amankwah, E. A., \& Barimah, J. (2013). Nutrients content and lipid characterization of seed pastes of four selected peanut (Arachis hypogaea) varieties from Ghana. African Journal of Food Science, 7(10), 375-381. http://doi.org/10.5897/AJFS12.136

Evita. (2012). Pertumbuhan dan hasil kacang tanah (Arachis hypogaea L.) pada perbedaan tingkatan kandungan air. Bioplantae, 1(1), 26-32.

Fischer, R. A., \& Maurer, R. (1978). Drought resistance in spring wheat cultivars . I Grain Yield Responses. Australian Journal of Agricultural Research - AUST J AGR RES, 29(5), 897-912.

Hetharie, H. (2008). Pengujian toleransi terhadap cekaman salinitas beberapa genotip lokal kacang hijau. Jurnal Budidaya Pertanian, 4, 132-139.

Kasno, A., \& Harnowo, D. (2009). Perbaikan toleransi kacang tanah terhadap cekaman lingkungan abiotik. In Monograf Balitkabi (Vol. 13, pp. 114132).

Departemen Kesehatan. (2015). Kandungan gizi pangan Indonesia. Retrieved from http://gizi.depkes.go.id/download/Ped oman Gizi/PGS Full.pdf

Koyro, H., Khan, M. A., \& Lieth, H. (2011). Halophytic crops: A resource for the future to reduce the water crisis? Emir. J. Food Agric., 23(1), 001-016.

Kristiono, A., Purwaningrahayu, R. D., \& Taufiq, A. (2013). Respons tanaman kedelai, kacang tanah, dan kacang hijau terhadap cekaman salinitas. 
Buletin Palawija, 26, 45-60.

Kusmiadi, R., Prayoga, G. I., Apendi, F., \& Alfiansyah. (2018). Karakterisasi morfologi plasma nutfah kacang tanah (Arachis hypogaea L.) Lokal Bangka. AGROSAINSTEK: Jurnal IImu Dan Teknologi Pertanian, 2(2), 61-66. https://doi.org/10.33019/agrosainstek .v2i 2.25

Ma'ruf, A. (2016). Respon beberapa kultivar tanaman pangan terhadap salinitas. Jurnal Penelitian Pertanian BERNAS, 12(3), 11-19.

Marwanto, S., Rachman, A., Erfandi, D., \& Subiksa, I. G. M. (2009). Tingkat salinitas tanah pada lahan sawah intensif di Kabupaten Indramayu, Jawa Barat. Bogor.

Marzuki, R. (2007). Bertanam kacang tanah. Jakarta: Penebar Swadaya.

Muharam. (2017). Efektivitas penggunaan pupuk kandang dan pupuk organik cair dalam meningkatkan pertumbuhan dan hasil tanaman kedelai (Glycine max L.) Varietas Anjasmoro di tanah salin. Jurnal Agrotek Indonesia, 2(1), 44-53.

Muliawan, N. R. E., Sampurno, J., \& Jumarang, M. I. (2016). Identifikasi nilai salinitas pada lahan pertanian di daerah Jungkat berdasarkan metode daya hantar listrik ( DHL ). Prima Fisika, 4(2), 69-72.

Nasyirah, N., Kalsim, D. K., \& Saptomo, S. K. (2015). Analisis laju pencucian tanah salin dengan menggunakan drainase bawah permukaan. Jurnal Keteknikan Pertanian, 3(2), 89-96. http://doi.org/10.19028/jtep.03.2.8996

Purwaningrahayu, R. D., \& Taufiq, A. (2017). Respon morfologi empat genotip kedelai terhadap cekaman salinitas. Jurnal Biologi Indonesia, 13(2), 175188.

Pusat Penelitian dan Pengembangan Tanaman Pangan. (2017). Toleran kacang tanah pada lahan salin. Retrieved from http://pangan.litbang.pertanian.go.id/ berita-893-toleran-kacang-tanahpada-lahan-salin.html

Taufiq, A., Kristiono, A., \& Harnowo, D. (2015). Respon varietas unggul kacang tanah terhadap cekaman salinitas. Penelitian Pertanian Tanaman Pangan, 34(2), 153-164.

Taufiq, A., \& Purwaningrahayu, R. D. (2013). Tanggap varietas kacang hijau terhadap cekaman salinitas. Penelitian Pertanian Tanaman Pangan, 32(3), 159-170.

Torey, P. C., Ai, N. S., Siahaan, P., \& Mambu, S. M. (2013). Karakter morfologi Akar sebagai indikator kekurangan air pada tanaman. Bioslogos, 3(2), 31-39.

Wijayanti, W., Taryono, \& Toekidjo. (2014). Keragaman 29 galur kacang tanah (Arachis hypogaea L.) pada kondisi salin. Vegetalika, 3(4), 40-51.

Yuniati, R. (2004). Penapisan galur kedelai (Glycine max L Merril) Toleran Terhadap $\mathrm{NaCl}$ untuk penanaman dilahan salin. Makara Sains, 8(1), 2124.

Yunita, S. R., Sutarno, \& Fuskhah, E. (2018). Respon beberapa varietas Kedelai (Glycine max L. Merr ) terhadap tingkat salinitas air penyiraman. Jurnal Agro Complex, 2(1), 43-51.

Yuwono, N. W. (2009). Membangun kesuburan tanah di lahan marginal. Jurnal Ilmu Tanah Dan Lingkungan, 9(2), 137-141. 